\title{
Electrospun Herbal Extract Derived Polymer Nanocomposites for Medical Applications
}

\author{
Sandra Jegina ${ }^{1}$, Anna Sutka ${ }^{2}$, Silvija Kukle ${ }^{3}$ \\ ${ }^{1-3}$ Institute of Design Technologies, Faculty of Materials Science and Applied Chemistry, Riga Technical University
}

\begin{abstract}
Herbal plants have been used in medicine since ancient times due to their health benefits. The research in this field continues to reveal advantages of these plants such as antibacterial activity against multidrug-resistant bacteria and possibility to integrate extracts in fibers by electrospinning. Electrospinning is a simple, yet versatile method of creating polymer-based nanofiber web, which can be used for wound dressings, tissue engineering and drug delivery systems. In production of electrospun nanofibers a solution of biocompatible polymer and a plant extract is needed. Therefore exploration of such composition ingredients is important.
\end{abstract}

Keywords - Nanofiber web, plant extracts, polymers, sodium chlorophyllin, electrospinning.

\section{INTRODUCTION}

The history of using plants to improve health is more than 5000 years long (1). Due to frequently reported side effects of medicaments, as well as due to their fully unknown long term effects on human health, more and more people prefer alternative or natural treatment over synthetic medicaments. The same tendency also applies to beauty industry. In herbal medicine (also called botanical medicine or phytomedicine) plant roots, leaves, bark, seeds, berries and flowers are used for medicinal purposes (2). In order to ensure the best quality of the final product it is crucial for raw materials to be ecologically clean. Utilization of locally grown plants ensures the sustainability of the manufacturing process. Biologically active substances from tree foliage and other plant biomass are used in food industry, pharmacy, cosmetics, plant protection, etc. (3). In Latvia production of sodium chlorophyllin by JSC Biolat (Latvia) is an excellent example of environmentally friendly recycling of tree greenery. External application of chlorophyll based preparations regenerate tissues in cases of wound, burn and bedsore treatments due to their bactericidal properties as well as the ability to prevent inflammation processes and to neutralize toxins (4). Sodium copper chlorophyllin has been widely researched (5).

In wound care electrospun nanofiber web with integrated bioactive ingredients is extensively used. The effectiveness of this method has been also scientifically proven in several biomedical applications such as tissue engineering, drug release, enzyme immobilization, etc. (6). To produce electrospun nanofibers web, a solution of polymer and extract spinning solution is used. Non-toxic and biodegradable polymers are the best choice for healthcare applications.
In this paper several common plant extracts which are suitable for medical applications and are compatible with polymers used for electrospinning are reviewed.

\section{II.EFFECTIVENESS OF PLANT EXTRACTS}

It is known that there are quite a few plants which cause health problems due to their toxicity and this information is publicly accessible (7). It is important to understand that nontoxic plants when prepared and used inappropriately become ineffective or toxic (8); therefore profound scientific research and monitoring of phytochemicals and their properties is needed in order to use them for medical applications.

\section{A. Sodium Chlorophyllin}

Sodium chlorophyllin (analogues of food additive E 141, according to the Codex Alimentarius (9)) is a component of neutralized extractive substances derived from spruce foliage. Sodium chlorophyllin contains derivatives of "a" and "b" chlorophyll (chlorines, sodium salts of chlorophylline acids, etc.), sodium salts of resinous acids (pimaric-, isopimaric-, abietic- and labdane types), sodium salts of fatty acids (mainly oleic-, stearic- and linoleic). Sodium chlorophyllin is used as an active food and colour additive, as well as in cosmetics (creams, deodorants, etc.). The product shows bacteriostatic, regenerative and deodorant properties (10).

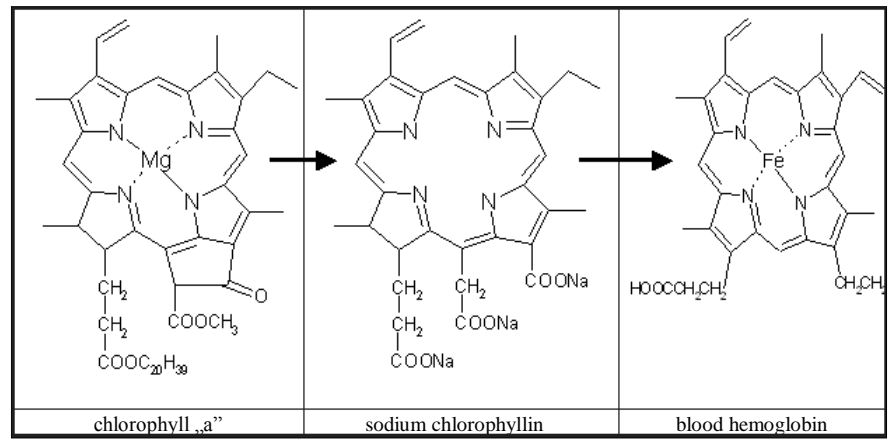

Fig. 1. Similarity of chlorophyll and blood hemoglobin structures (4).

Due to similarity of structures of chlorophyll and blood hemoglobin (Fig. 1) chlorophyllin is effective for (4):

- strengthening of immune system;

- stabilizing the fluid balance in the body;

- improving blood structure, rendering toning up and deodorizing (removes bad breath);

- healing ulcers;

- anemia treatment; 
- inhibiting the development of atherosclerosis and psoriasis;

- for photodynamic therapy in cases of tumours.

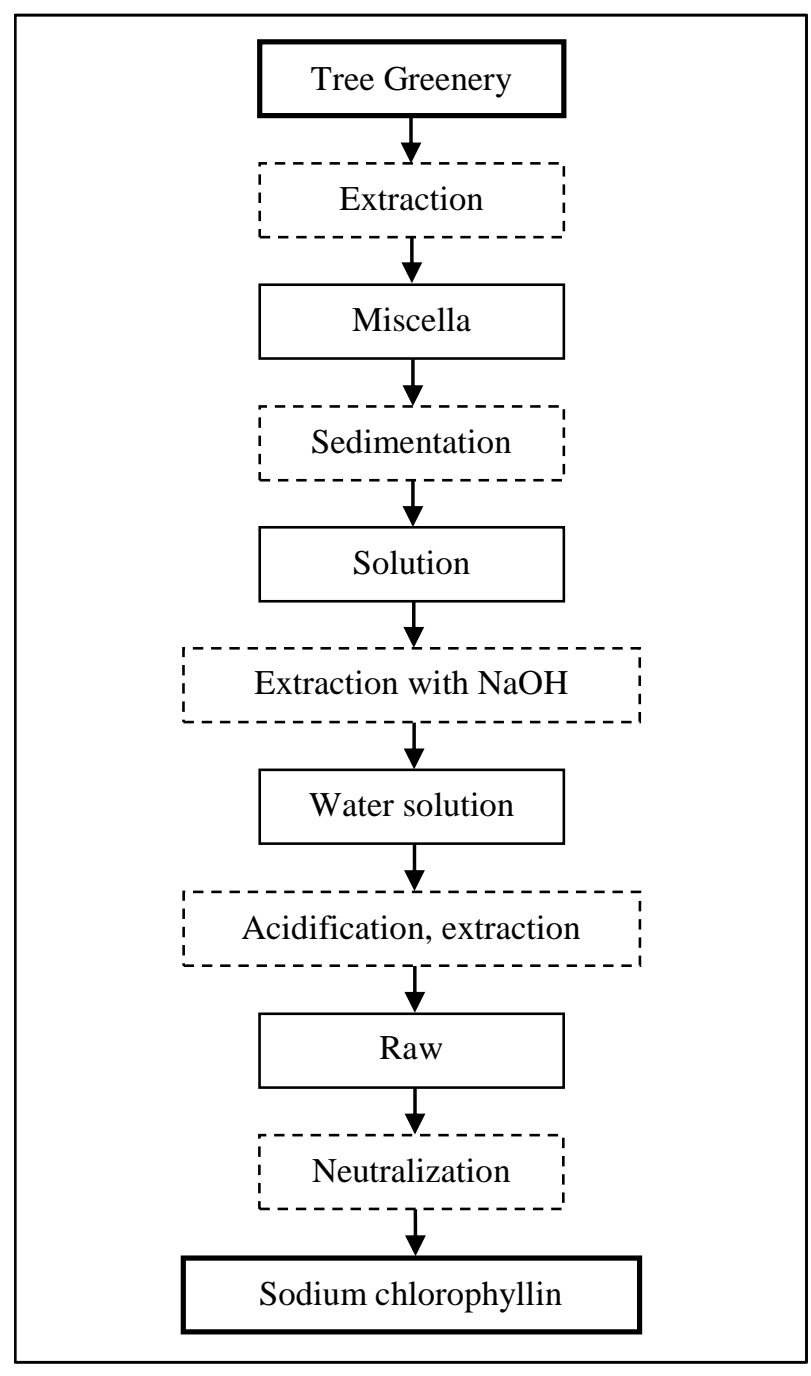

Fig. 2. Scheme of acquisition of sodium chlorophyllin (11).

Due to its ability of to form molecular complexes with carcinogens and thereby to block their bioavailability, chlorophyllin was recently evaluated as a chemopreventive agent in a population at a high risk for exposure to aflatoxin and the subsequent development of hepatocellular carcinoma (11).

Laboratory scale microbiological tests were performed to determine the effect of sodium chlorophyllin on human dermal cells (20). Although further research is needed, the results confirmed the bioactivity of sodium chlorophyllin on human cells.

\section{B. Herbal Extracts with Antibacterial Activity against Multidrug- Resistant Bacteria}

Antibiotics are often prescribed to treat infections because of their effectiveness in severe cases. However bacteria tend to develop antibiotic resistance which, in turn, leads to development of multiresistant infectious disease organisms. Such infections are hard or sometimes impossible to treat (12).
To avoid such problems plant extracts with antibacterial properties against multidrug- resistant (MDR) strains of bacteria are evaluated, such as Escherichia coli, Klebsiella pneumoniae and Candida albicans (13). In this study the antibacterial and antifungal activity of ethanolic extracts of Acacia nilotica, Terminalia arjuna, Eucalyptus globulus, Syzygium aromaticum and Cinnamomum zeylanicum against multi-drug resistant strains isolated from nosocomial and community acquired infections was investigated.

Dried leaves of A. nilotica, E. globulus, dried bark of T. arjuna, C. zeylanicum, dry buds of S. aromaticum were pulverized or ground into coarse powder and then suspended in $50 \%$ or $90 \%$ ethanol for 1 or 7 days. After filtration and evaporation of ethanol the extracts were oven dried at $60{ }^{\circ} \mathrm{C}$. For experiments each extract was dissolved in ethanol to the desired concentration (14).

Test results revealed that only three plant extracts A. nilotica, C. zeylanicum and S. aromaticum had necessary bioactive properties which could be used against multidrugresistant microorganisms. In conclusion the authors stated that for further research the toxicity of the active constituents, their side effects and pharmaco-kinetic properties should be determined (13).

\section{Plant Extracts with Activity against Oral Bacteria}

Oral health influences the general quality of life and poor oral health is linked to chronic conditions and systemic diseases (15). Oral bacteria are also prone to develop multidrug resistance and, therefore, alternative treatments are researched. Chloroform extracts of leaves of Drosera peltata (Droseraceae) showed greatest activity against $S$. mutans and S. sobrinus bacteria. Extracts of Abies Canadensis (Pinaceae), Albizia julibrissin (Fabaceae), Chelidonium majus (Papaveraceae), Ginkgo biloba (Ginkgoaceae), Juniperus virginiana (Cupressaceae), Pinus virginiana (Pinaceae), Rosmarinus officinalis (Lamiaceae), Sassafras albidum (Lauraceae), Tanacetum vulgare (Asteraceae) and Thuja plicata (Cupressaceae) have been proven to be effective for inhibition of the growth of oral streptococci (15).

There are numerous denominations of the plants which performed well in bioactivity tests. But only one (Harungana madagascariensis (Hypericaceae)) was mentioned to have an enhanced effect when combined with polymer. An ethyl acetate extract of leaves of native African plant was prepared and tested against numerous oral pathogens. While the extract was able to kill all oral bacteria tested (including Actinomyces, Fusobacterium, Lactobacillus, Prevotella, Propionibacterium and Streptococcus species), poly (d,1-lactide-co-glycolide) nanoparticles containing the extract showed enhanced activity. The authors suggested that this may have been due to the bioadhesive properties of the polymer resulting in the extract being in contact with the bacteria for prolonged periods (15). In this case the polymer enhanced the bioactive properties of the extract and improved overall antibacterial activity results. 


\section{EleCtrospun BIO-NANOCOMPOSITES, CHALLENGES AND APPLICATIONS}

The combination of herbal medicine and nanotechnology may provide improved bioavailability and less toxicity (16). Solution of biocompatible polymers and some plant extracts can be successfully used in electrospinning.

The properties of the electrospun nanofibers ensure their usability for bio-nanocomposites in medical applications; therefore, acquisition methods, that would be effective and successfully integrated not only in laboratories, but also in the production, are investigated. Electrospinning makes it possible to combine the advantages of utilizing plant materials in the form of nanofibrous scaffolds for delivering the active constituent at a sufficient concentration during the entire treatment period (17).

Disadvantages of natural polymers include: the lack of molecular weight control, chain configuration and polymerization kinetics, versatility of chemistry. But advantages over synthetic polymers are: low cost, biocompatibility, non-toxicity, and biodegradability (17). Most of the natural biopolymers are electrospun using organic solvents which may prove toxic for tissue engineering applications. Fabricated scaffolds may contain a small amount of organic solvent that could affect cell growth and proliferation. Therefore, electrospinning of biocompatible polymers (Table I) using aqueous solvents will help to overcome this problem and is highly desirable for cell culture and tissue engineering (18).

TABLE I

SPINNABLE, BIOCOMPATIBLE AND BIODEGRADABLE POLYMERS (19)

\begin{tabular}{|l|l|}
\hline Polymer & Solvent \\
\hline Polyurethanes, PU & dimethylformamide \\
\hline Polyvinyl alcohol, PVA & distilled water \\
\hline Polylactic acid, PLA & $\begin{array}{l}\text { dimethylformamide, } \\
\text { dichloromethane }\end{array}$ \\
\hline Polycaprolactone, PCL & $\begin{array}{l}\text { chloroform, toluene, } \\
\text { dichloromethane }\end{array}$ \\
\hline Polyethylene glycol, PEG & chloroform \\
\hline $\begin{array}{l}\text { Poly(lactide-co-glycolide), } \\
\text { PLGA }\end{array}$ & $\begin{array}{l}\text { mixture of tetrahydrofuran and } \\
\text { dimethylformamide }\end{array}$ \\
\hline $\begin{array}{l}\text { Poly(ethylene-co-vinyl } \\
\text { acetate), PEVA }\end{array}$ & $\begin{array}{l}\text { mixture of isopropanol and } \\
\text { water }\end{array}$ \\
\hline $\begin{array}{l}\text { Poly(ethylene-co-vinyl } \\
\text { alcohol), PEVOH }\end{array}$ & $\begin{array}{l}\text { distilled water, chloroform, } \\
\text { acetone }\end{array}$ \\
\hline Poly(ethylene oxide), PEO & hexafluoro-2-propanol \\
\hline Collagen &
\end{tabular}

A. Electrospinning of Sodium Chlorophyllin/Polymer Nanocomposite

Laboratory scale microbiological tests were performed to determine the effect of sodium chlorophyllin on human dermal cells (20). In this research the effect of sodium chlorophyllin on polyvinyl alcohol (PVA) electrospun nanofiber web composite with sodium chlorophyllin were analyzed. Properties of PVA spinning solution were also tested in order to evaluate the effects of added sodium chlorophyllin. Sodium chlorophyllin affects such properties of the spinning solution as: viscosity and electrical conductivity, morphology of nanofiber web, diameter of nanofibers and also mechanical properties. Although further research is needed, the results confirmed the bioactivity of sodium chlorophyllin on human cells.

\section{B. Electrospinning Challenges}

There are several key issues in order to ensure quality electrospinning of nanofibers webs - nanofibers with controlled and uniform dimensions, ability to place them in desired patterns, tailorable and controllable physical, mechanical, chemical, biological, optical and electrical properties (19). The following aspects should be considered when modelling nanofibres - molecular weight, crystallinity (\%), orientation of crystallites, porosity of nanofibers and sizedependency via surface modulus (19).

\section{Electrospinning in Wound Dressing}

The advantages of electrospinning in production of wounddressing materials are: oxygen permeation, protection of wound from infection and dehydration and homogenous scaffold (6). Many synthetic and natural polymers (carboxyethyl chitosan/PVA, collagen/chitosan, silk fibroin, ABA type poly(dioxanoneco-L-lactide)-block-poly(ethylene glycol) (PPDO/PLLA-b-PEG) block copolymer) have been electrospun for wound-dressing applications (21). In vitro culture studies of human dermal fibroblasts on electrospun PCL collagen blend nanofibrous membranes are shown to be promising as dermal substitute for the treatment of skin defects and burn wounds (6).

\section{Manufacturers of Products for Medical Applications}

According to the online directory (22) of service suppliers of electrospun products, there are several companies which produce electrospun fibers for medical applications. Biomimetic Electrospinning Technologies Inc. (USA) customized scaffolds for biomedical application, BioSurfaces Inc. (USA) - drug loaded electrospun fibers for medical applications, Neotherix (United Kingdom) - manufactures nanofiber scaffolds for tissue regeneration, PolyRemedy (USA) - wound care system, Stellenbosch Nanofiber Company (South Africa) - develops and manufactures nanofiber based materials for medical applications and The Electrospinning Company (United Kingdom) - manufactures nanofiber scaffold for tissue regeneration.

\section{CONCLUSION}

Plants have been used for health purposes since ancient times. There are many written evidences with specific recipes and descriptions of use. Sodium chlorophyllin has many beneficial health improving properties, especially in regeneration of tissues, and, therefore, it may be suitable for wound healing.

Studies have shown that many different plant extracts have impressive antibacterial properties, including: activity against multidrug-resistant bacteria, although further research is needed to determine the possible toxicity. Biocompatible and 
biodegradable polymer solutions should be used in combination with plant extracts to ensure biological safety. Such nanofiber web has promising future in wound care.

\section{REFERENCES}

1. Bauer Petrovska, B. Historical review of medicinal plants' usage. Pharmacognosy Reviews, 2012, vol. 6, issue 11, pp. 1-5. http://dx.doi.org/10.4103/0973-7847.95849

2. Neustadt, J., Pieczenik, S. Foundations and Applications of Medical Biochemistry in Clinical Practice. Bloomington: iUniverse, 2009

3. Hogeforster, M. Strategies and Promotion of Innovation in Regional Policies around the Mare Balticum. Norderstedt: Baltic Sea Academy e.V., 2012

4. "Biolat" JSC. Food enrichers Health drink "HO-FI" [Online]. Salaspils (LV): "Biolat" JSC, [Accessed 5.10.2015.]. Available: http://www.biolat.lv/35/section.aspx/16

5. Tumolo, T., Lanfer-Marquez, U. M. Copper chlorophyllin: A food colorant with bioactive properties? Food Research International,

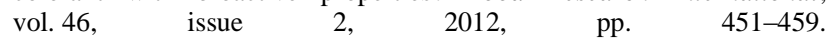
http://dx.doi.org/10.1016/j.foodres.2011.10.031

6. Agarwal, S., Wendorff, J. H., Greiner, A. Use of electrospinning technique for biomedical applications. Polymer, vol. 49, 2008, pp. 56035621. http://dx.doi.org/10.1016/j.polymer.2008.09.014

7. European Food Safety Authority, Compendium of botanicals that have been reported to contain toxic, addictive, psychotropic or other substances of concern on request of EFSA. EFSA Journal, 2009, vol. 7, 9:281. [Report] Available: www.efsa.europa.eu

8. Ekor, M. The growing use of herbal medicines: issues relating to adverse reactions and challenges in monitoring safety. Frontiers in Pharmacology, 2014, 4:177. http://dx.doi.org/10.3389/fphar.2013.00177

9. FAO/WHO. Codex Alimentarius International Food Standards (Codex STAN 192-1995), Roma: FAO, 2014.

10. „Biolat” Joint Stock Company. Sodium chlorophyllin. [Online]. Salaspils (LV): "Biolat" JSC, [Accessed 5.10.2015.]. Available: http://biolat.lv/85/section.aspx/59

11. Siksna, S., Daberte, I., Barene, I., Iriste, V. Coniferous greenery valuable natural raw material of biologically active substances. Medicinos teorija ir praktika (Theory and Practice in Medicine), 2012, T.18, 2, pp. 146-148.

12. Levy, S. B. Factors impacting on the problem of antibiotic resistance. Journal of Antimicrobial Chemotherapy, 2002, vol. 49, pp. 25-30. http://dx.doi.org/10.1093/jac/49.1.25

13. Khan, R., Islam, B., Akram, M. et al. Antimicrobial Activity of Five Herbal Extracts Against Multi Drug Resistant (MDR) Strains of Bacteria and Fungus of Clinical Origin. Molecules, 2009, vol. 14, pp. 586-597. http://dx.doi.org/10.3390/molecules14020586

14. Khan, R., Islam, B., Akram, M. et al. Antimicrobial Activity of Five Herbal Extracts Against Multi Drug Resistant (MDR) Strains of Bacteria and Fungus of Clinical Origin. Molecules, 2009, vol. 14, p. 593. http://dx.doi.org/10.3390/molecules14020586

15. Palombo, E. A. Traditional Medicinal Plant Extracts and Natural Products with Activity against Oral Bacteria: Potential Application in the Prevention and Treatment of Oral Diseases. Evidence-Based Complementary and Alternative Medicine, 2011, Article ID 680354, p. 15. http://dx.doi.org/10.1093/ecam/nep067

16. Sahu, A.N. Nanotechnology in herbal medicines and cosmetics. International Journal of Research in Ayurveda \& Pharmacy, 2013, vol. 4, issue 3, pp. 472-474. http://dx.doi.org/10.7897/2277-4343.04334

17. Venugopal, J., Sreepathy, S., Ramakrishna, S. Electrospun plant-derived natural biomaterials for Tissue engineering. Plant Science Today, 2014, vol. 1, issue 3, pp. 151-154. http://dx.doi.org/10.14719/pst.2014.1.3.65

18. Venugopal, J., Sreepathy, S., Ramakrishna, S. Electrospun plant-derived natural biomaterials for Tissue engineering. Plant Science Today, 2014, 1, 3, p. 153. http://dx.doi.org/10.14719/pst.2014.1.3.65

19. Ramakrishna, S. Polymer Nanofibers in Medicine, Biotechnology \& Engineering [Online]. International Congress of Nanotechnology, 2004, [Accessed 6.10.2015.]. Available: http://www.ianano.org/Presentation/Ramakrishna-NUS-11-10-GW3.pdf

20. Jegina, S. Innovative and Biologically Active Nanostructured Nonwovens for Medical Applications. Master Thesis, RTU Institute of Design Technologies, 2015.

21. Agarwal, S., Wendorff, J. H., Greiner, A. Use of electrospinning technique for biomedical applications. Polymer, vol. 49, 2008, pp. 56175618. http://dx.doi.org/10.1016/j.polymer.2008.09.014

22. ElectrospinTech. Electrospun Products/Service Suppliers [Online]. Webbased information and discussion portal [Accessed 7.10.2015.]. Available: http://electrospintech.com/espin-companies.html\#.Vh3I0Csv9hY

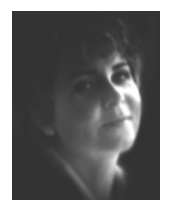

Sandra Jegina, Mg. sc. ing. (RTU, 2015) is a doctoral student and scientific assistant at Institute of Design Technologies, Riga Technical University. Currently she continues research of the effects of sodium chlorophyllin on polyvinyl alcohol (PVA) electrospun nanofiber web.

Address: Institute of Design Technologies, Riga Technical University, Kipsalas Str. 6, Riga, LV-1048, Latvia.

E-mail: sandra.jegina@edu.rtu.lv

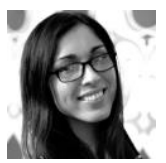

Anna Sutka, Dr. sc. ing. (RTU, 2015) is a researcher at Institute of Design Technologies and an engineer at Laboratory of Biomass Eco-Efficient Conversion, Latvian State Institute of Wood Chemistry. Her specialization is Material Technology and Design and her qualification is Product Designer (Mg. sc. ing., RTU, 2011).

Address: Institute of Design Technologies, Riga Technical University, Kipsalas Str. 6, Riga, Latvia, LV-1048.

E-mail: anna.sutka@rtu.lv

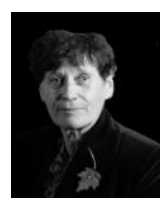

Silvija Kukle, Dr. habil. sc. ing., since 1994 is a Professor at Institute of Design Technologies, Riga technical University. She graduated from RPI in 1965 and obtained a qualification of an engineer-technologist. In 1977, she received a scientific degree Candidate of Technical Sciences. In 1991 she obtained a Doctoral degree in Engineering Sciences. She obtained the degree Habilitated Doctor in 1993. Silvija Kukle is a Head of Professors' Group of Technology and Design.

Address: Institute of Design Technologies, Riga Technical University, Kipsalas Str. 6, Riga, Latvia, LV-1048.

E-mail: silvija.kukle@rtu.lv

\section{Sandra Jēgina, Anna Šutka, Silvija Kukle. Elektrovērptu augu ekstraktu/polimēru nanokompozītu lietojums medicīnā}

Augu ekstraktu izmantošanai ārstniecībā ir sena vēsture, un par to saglabājušāas daudzas liecības. Mūsdienās arvien biežāk cilvēki izvēlas dabiskus un nekaitīgus ārstniecības līdzekḷus, jo bieži vien nepamatota antibiotiku lietošana izraisa baktēriju rezistenci, kā arī citas sintētisko medikamentu izraisītās blaknes, kas samazina dzīves kvalitāti. Pasaules Veselības organizācijas statistikas dati liecina, ka vairāk nekā 80 \% iedzīvotāju dod priekšroku augu valsts preparātiem. Latvijā viens no šādiem dabiskiem līdzekḷiem ar izteiktām ārstnieciskajām īpašībām ir skuju nātrija hlorofilīns. Pētijjumos pierādīts, ka nātrija hlorofilīns ir savietojams ar polivinilspirta šksīdumu. No šāda šksīduma ar elektrovērpšanas metodi ir izdevies iegūt nanotīmekli un analizēt tā iedarbību uz cilvēka dermas šūnām. Rakstā apskatītie pētījumi pierāda, ka daudziem augu ekstraktiem piemīt izteikta antibakteriālā iedarbība. Tomēr ieteikts veikt tālāku izpēti, lai izvērtētu toksisku sastāvdaļu iespējamību. Lai nodrošinātu ekologiskumu un nekaitīgumu cilvēka veselībai, elektrovērpšanā vislabāk izmantot biosaderīgus un bionoārdošus polimērus. Elektrovērpto nanotīmekḷ kvalitāte ir atkarīga no katras atsevišksas šḳiedras vienmērības, kā arī no to mehāniskajām, ķīmiskajām un biologiiskajām īpašībām. Nanošķiedru materiālu izmantošana brūču aprūpē būtiski uzlabo ārstēšanas rezultātus. Medicīnā izmantojamo nanokompozītu ražošanas firmu pastāvīgi augošais skaits pierāda progresīvu materiālu medicīniskam pielietojumam nepieciešamību. 
Сандра Егина, Анна Шутка, Силвия Кукле. Применение в медицине электроформованных нанокомпозитов экстрактов растений/полимеров

Употребление экстрактов лекарственных трав в медицине известно с древних времён и об этом сохранились многочисленные письменные свидетельства. В наше время, когда употребление антибиотиков вызывает антибиотикорезистентность и побочные эффекты от синтетических медикаментов ухудшают жизненное качество, больше людей предпочитают пользоваться натуральными и безвредными для здоровья препаратами. В Латвии один из таких препаратов с особо выраженными лечебными свойствами является хвойный хлорофиллин натрия. В исследованиях подтвердилось, что хлорофиллин натрия совместим с поливинилспиртом. В процессе электроформования полученные нановолокна были тестированы в лаборатории на человеческих клетках дермы. В этой публикации упомянутые исследования указывают, что многие растительные экстракты обладают ярко выраженными антибактериальными свойствами, но рекомендовано продолжить исследования, чтобы проверить эти экстракты на токсичность. Для сохранения экологичности и безвредности человеческому здоровью, в электроформовании лучше всего использовать биосовместимые и биоразлагающиеся полимеры. Качество электроформованнх нановолокон зависит от их однородности, а также от механических, химических и биологических свойств. Использование материалов из нановолокн в лечение ран заметно улучшает результаты лечения О том, что на данные продукты имеется спрос, говорит постоянно растущее количество тех фирм, которые производят прогрессивные нановолокна. 